\title{
A pilot scale study on the concentration of milk and whey by forward osmosis
}

George Q. Chen ${ }^{1}$, Anna Artemi ${ }^{2}$, Judy Lee ${ }^{2}$, Sally L. Gras ${ }^{1,3}$, Sandra E. Kentish ${ }^{1 *}$

1 The ARC Dairy Innovation Hub, Department of Chemical Engineering, The University of Melbourne, Parkville, Victoria 3010, Australia

2 Department of Chemical and Process Engineering, University of Surrey, Guildford, Surrey GU2 7XH, United Kingdom

${ }^{3}$ The Bio21 Molecular Science and Biotechnology Institute, The University of Melbourne, Parkville, Victoria 3010, Australia

Keywords: Forward osmosis; dairy; PAO mode; clean-in-place.

${ }^{*}$ Corresponding Author

Prof S. Kentish

Tel: +61383446682

Fax: +61 383444153

E-mail address: sandraek@unimelb.edu.au 


\begin{abstract}
The concentration of skim milk and whey was investigated at a pilot scale using forward osmosis membranes with an installed membrane area of $24 \mathrm{~m}^{2}$. The pilot plant was operated in batch mode using a draw solution (48-57 $\mathrm{g} / \mathrm{L}$ of $\mathrm{NaCl}$ ) that mimics the potential brine streams available in a dairy processing plant. This approach avoids or limits the need for the regeneration of a synthetic draw solution. A concentration factor of $\sim 2.5$ was achieved for both the skim milk and fresh whey, resulting in a total solids concentration of $\sim 21 \mathrm{wt} \%$ and $15 \mathrm{wt} \%$, respectively. Increasing the transmembrane pressure was found to be effective in improving the water flux, whereas a much greater increase in the draw solution osmotic pressure would be needed to achieve the same enhancement of flux. This study also showed that small organic molecules, such as lactose, were not fully rejected by the forward osmosis membranes. A cleaning protocol was established for recovering the membrane performance after milk and whey concentration. The specific energy required for milk and whey concentration using only the forward osmosis step ( $5-10 \mathrm{kWh} / \mathrm{t}$ water removed) is much lower than that required by reverse osmosis. Forward osmosis is an energy efficient and effective process for dairy applications if unlimited access to a brine stream can be made available within or in the proximity of dairy processing plants.
\end{abstract}




\section{1. INTRODUCTION}

2 Milk and whey powders are the main spray dried products manufactured by the dairy industry. Milk

3 is a natural source of calcium and other essential nutrients, such as proteins and vitamins. Whey is a

4 by-product produced during cheese manufacturing, which is low in carbohydrates, fat and calories

5

6

7 and rich in proteins that contain all nine essential amino acids. In dairy processing, large quantities of milk and whey proteins are processed to powder each year. Concentration and drying processes demand $\sim 25 \%$ of the total energy consumption, making them the most energy intensive processes in dairy processing plants [1]. Conventionally, evaporative operations are utilized to remove $90 \%$ of the water during the concentration step, while the remaining $10 \%$ is removed during the drying process. Hence, increasing the total solids concentration prior to drying by means of less energy consuming unit operations is of great interest to dairy processors. Nanofiltration (NF) and reverse osmosis (RO) are often applied as a pre-concentration step, as these pressure driven processes are known to be over ten times more energy efficient compared to thermal evaporation [2]. Due to the rising osmotic pressure and the extensive fouling issues caused by the formation of protein and calcium phosphate deposits, these processes are limited by the maximum achievable total solid concentrations and the declining filtration efficiency.

Forward osmosis is an emerging membrane technology that was initially developed for desalination, water reclamation and brine concentration. Unlike reverse osmosis, where a high hydraulic pressure is applied, forward osmosis relies on the natural flow of water through a semi-permeable membrane driven by an osmotic pressure gradient between a feed solution of low ionic strength to a draw solution of higher ionic strength. Compared to conventional membrane processes, it exhibits the advantages of higher water recovery, higher achievable solids concentration, greater resistance to fouling problems and potentially greater energy efficiency [2]. Heat degradation of dairy products can be avoided, as FO processes can be operated at low temperatures. Therefore, forward osmosis is a valuable process worthy of investigation for concentration of dairy streams prior to drying. A series of studies on this topic have been reported by Aydiner et al. [3-5], who focused on the recovery of water from whey, as well as the technical and economic performance of hybrid systems, where the regeneration of the draw solution is achieved by reverse osmosis and membrane distillation. This research group has also recently investigated the use of a mixture of ammonia and carbon dioxide $\left(\mathrm{NH}_{3} / \mathrm{CO}_{2}\right)$ salts as the draw solution for whey concentration using forward osmosis [6, 7]. Regeneration of such draw solutions, however, is energy intensive. More recently, the concentration of re-constituted whey protein solutions was investigated by Wang et al. [8] under different crossflow velocities and sodium chloride draw solution concentrations, using hollow fiber polyamide thin film composite membranes. 
To minimize the need for the energy- intensive regeneration step, saline streams that are available in a typical dairy processing facility can be used as the draw solution (see Figure 1). For example, the production of semi-hard and hard cheese uses dry salt or a brine solution (highly concentrated salt solution) to extract the moisture from the cheese curd. This is followed by a pressing step where the excess moisture is expelled from the curd, together with a significant portion of the added salt, forming a waste product called salty whey. Salty whey is high in ionic strength (conductivity: 39-127 $\mathrm{mS} / \mathrm{cm}$ ), containing $\sim 26-78 \mathrm{~g} / \mathrm{L}$ of $\mathrm{NaCl}$ [9]. This makes this stream a suitable draw solution to be used in a forward osmosis process. Other saline streams that exhibit similar or higher salt concentrations include ion exchange and chromatography regeneration brines, or the brine from evaporation ponds [10]. Each of these streams could be discharged in a similar manner to current practice after use.

To date, there is only a limited number of large scale forward osmosis demonstrations reported for desalination applications. The world's first commercial forward osmosis desalination plant was built and operated by Modern Water (UK) in Oman in 2011 [11]. More recently, forward osmosis has been employed on an industrial scale by Oasys Water (USA), as the brine concentration technology within a zero liquid discharge technology train, for water reclamation in a 2 × $660 \mathrm{MW}$ steam generator power plant in China [12]. Smaller pilot scale forward osmosis processes have also been demonstrated for desalination of mine impaired water for fertigation [13], treatment of oilfield wastewater [16], produced water from natural gas extraction operations [17], sewage [16, 18], brackish [14, 15] and municipal wastewater [19]. No pilot scale study has been reported, however, for the application of forward osmosis in the dairy industry. Such an upscaling study can provide useful information to optimize FO technology and accelerate the commercialization of this technology in dairy processing.

In this work, the concentration of skim milk and dairy whey is investigated at pilot scale using an 8" membrane module fitted with two commercial scale cellulose triacetate forward osmosis membrane elements. A brine solution comparable in composition to salty whey was used as the draw solution. The effect of temperature, transmembrane pressure, as well as variation of osmotic driving force on system performance was investigated. Since cellulose acetate membranes are known to have a narrow range of $\mathrm{pH}$ tolerance [20], an enzymatic cleaning protocol is also evaluated to avoid using strong acids or base for membrane cleaning and regeneration. 


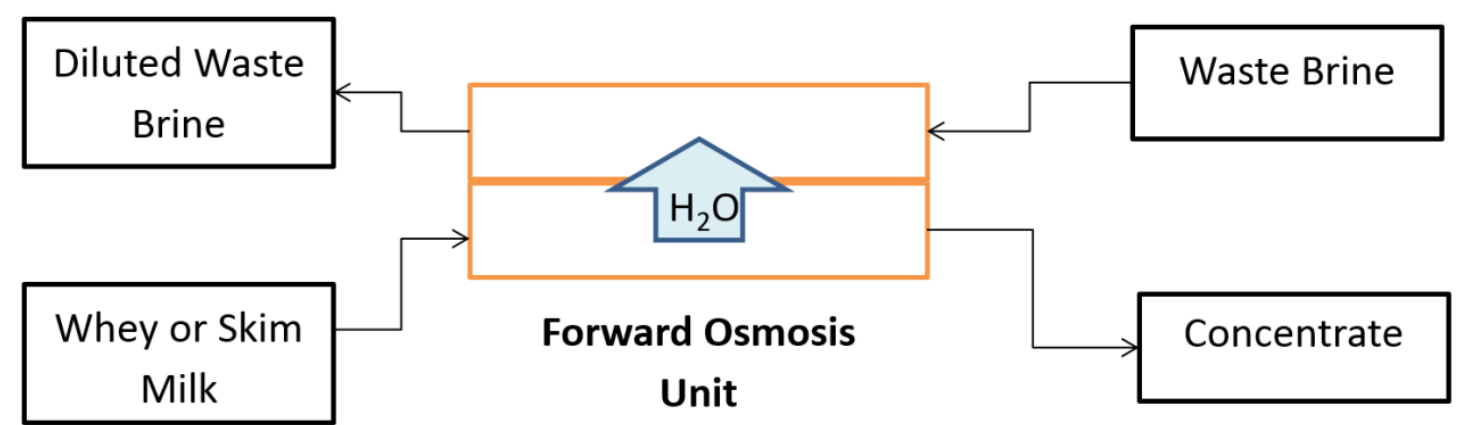

Figure 1: The proposed concentration process of milk or whey by forward osmosis. A waste brine within the dairy processing plant is used as the draw solution. The black arrows indicate process flow and the blue arrow indicates the migration of water into the draw stream.

\section{EXPERIMENTAL}

\subsection{Materials}

Sodium chloride (99.5\%, for analysis) was supplied by Fisher Scientific UK Ltd. The cleaning chemicals, including an enzyme blend and a neutral buffer were generously provided by Holchem Laboratories Ltd (UK). The enzyme blend contains protease, lipase, amylase (alpha) and pectate enzymes amongst others. The neutral buffer is a detergent additive for use to adjust pH before adding the enzyme blend. Skim milk was procured from Tesco Supermarket, UK. Fresh whey samples were collected from a small local dairy company (High Weald Dairy, UK). The general characteristics of the milk and whey sample are shown in Table 1. 
Table 1: The composition of the skim milk and whey samples used in this work. Errors are standard 79 deviations $(n=3)$.

\begin{tabular}{|l|c|c|c|c|}
\hline Characteristic & Unit & Skim Milk & Whey Sample A & Whey Sample B \\
\hline $\mathrm{pH}$ & - & $6.89 \pm 0.09$ & $5.07 \pm 0.06$ & $4.79 \pm 0.05$ \\
\hline Conductivity & $\mathrm{mS} / \mathrm{cm}$ & $4.6 \pm 0.3$ & $12.9 \pm 0.8$ & $7.6 \pm 0.5$ \\
\hline Lactose & $\mathrm{g} / \mathrm{L}$ & $36.9 \pm 0.7$ & $37.2 \pm 0.7$ & $43.1 \pm 0.9$ \\
\hline Total Solids & $\mathrm{g} / 100 \mathrm{~g}$ & $8.2 \pm 0.3$ & $5.1 \pm 0.3$ & $5.9 \pm 0.4$ \\
\hline Ash & $\mathrm{g} / 100 \mathrm{~g}$ & $0.73 \pm 0.04$ & $0.77 \pm 0.04$ & $0.55 \pm 0.03$ \\
\hline Protein\# & $\mathrm{g} / 100 \mathrm{~g}$ & 3.28 & $\mathrm{NA}$ & 0.94 \\
\hline Fat & $\mathrm{g} / 100 \mathrm{~g}$ & 0.1 & $\mathrm{NA}$ & 0.3 \\
\hline Osmolality & $\mathrm{mmol} / \mathrm{kg}$ & $335 \pm 5$ & $363 \pm 4$ & $293 \pm 3$ \\
\hline
\end{tabular}

NA: not analysed

\#: Analysis performed by ALS Food and Pharmaceutical, Chatteris, United Kingdom.

The Cellulose Triacetate (CTA) FO membrane elements were purchased from Fluid Technology Solutions, Inc., USA (FTSH2O). These elements (OsmoF2O FO-CTA-8040-45-SDS, active area $12 \mathrm{~m}^{2}$ ) are fitted with medium feed spacers for low-fouling fluids with standard brine draw solution spacers and contained within fiber-glass wrap. The main properties of the CTA membrane elements are summarised in Table 2. An 8", 2 element vessel (ROPV R80B300S pressure vessel) was purchased from Hydropure A/Asia Pty Ltd, Queensland, Australia. The membrane module was assembled in the UK with two FTSH2O FO elements connected by an interconnector supplied by FTSH2O.

Table 2: Properties of OsmoF2O FO membrane.

\begin{tabular}{|l|c|c|}
\hline Description & Unit & Value \\
\hline Membrane type & - & Cellulose Triacetate (CTA) \\
\hline Configuration & - & $\begin{array}{c}\text { Side Ports (Feed Solution) } \\
\text { End ports (Draw Solution) }\end{array}$ \\
\hline Max. operating temperature & ${ }^{\circ}$ C & 50 \\
\hline Max. side port pressure & bar & 0.35 \\
\hline $\begin{array}{l}\text { Min. Transmembrane Pressure (side ports vs. } \\
\text { end ports) to prevent element seam failure }\end{array}$ & bar & 3 to 7 \\
\hline pH operating range & - & 12 \\
\hline Active area & $\begin{array}{c}\mathrm{m}^{2} \text { per } \\
\text { element }\end{array}$ & \begin{tabular}{c} 
(C) \\
\hline Draw solution $\mathrm{NaCl}$ rejection
\end{tabular} \\
\hline
\end{tabular}




\subsection{Pilot scale forward osmosis plant}

The pilot scale forward osmosis plant was designed at the University of Surrey, UK and manufactured by Axium Process Ltd, UK. The 8" FO membrane module, as described above, is used in a countercurrent configuration. As shown in Figure 2, the feed solution(FS) is fed from a feed tank through the side ports of the membrane module. The draw solution(DS) is pumped through the module using the end ports. Both the feed and draw solution holding tanks have a capacity of $>250 \mathrm{~L}$. The feed tank sits on a weighing scale (Sartorius F 150S-* D2, weighing range $0.5-151 \mathrm{~kg}$ ). Centrifugal pumps (Model No. CRIE 10-3 and CRIE 1-3) manufactured by Grundfos, Denmark were used for pumping the feed and draw solutions. Filtration was performed with the membrane module in FO mode, where the active and support layers faced the feed and draw solutions, respectively.

All experiments were conducted in batch mode, unless otherwise stated. An initial volume of $140 \mathrm{~L}$ of milk or whey was used as the feed solution unless otherwise stated. The initial volume of the draw solution was then selected based on the size of the draw solution tank ( $250 \mathrm{~L}$ ) to allow for a maximum concentration factor of 2.5 of the feed solution (i.e. $140 \mathrm{~L}$ to $56 \mathrm{~L}$ ). This would add at most $84 \mathrm{~L}$ of water into the draw solution, so an initial volume of $160 \mathrm{~L}$ ensures that the final volume $(244 \mathrm{~L})$ can be accommodated. During the concentration process, the mass of the feed solution, the volume of the draw solution and the conductivity of the feed and draw solutions were recorded as a function of time. The temperature and pressure of the inlet and outlet of both the feed and draw solution sides of the membrane module were also monitored through all experiments. Sodium chloride solutions were used as the draw solution, with an initial concentration of $50 \mathrm{~g} / \mathrm{L}$, unless otherwise stated. This concentration mimics the ionic strength of a typical saline water (e.g. salty whey) that is likely available in a dairy processing facility. All experiments were conducted at room temperature $\left(16-19^{\circ} \mathrm{C}\right)$, except for a low temperature run at $\left(9.3-15^{\circ} \mathrm{C}\right)$ for skim milk. The feed and draw solution flowrates were 45.6 $\pm 2.3 \mathrm{~L} / \mathrm{min}$ and $7.5 \pm 0.2 \mathrm{~L} / \mathrm{min}$, respectively, unless otherwise stated. These volumetric flow rates were selected to ensure the transmembrane pressure along the spiral wound module was kept above 0.35 bar (Table 2), as specified by the manufacturer. 


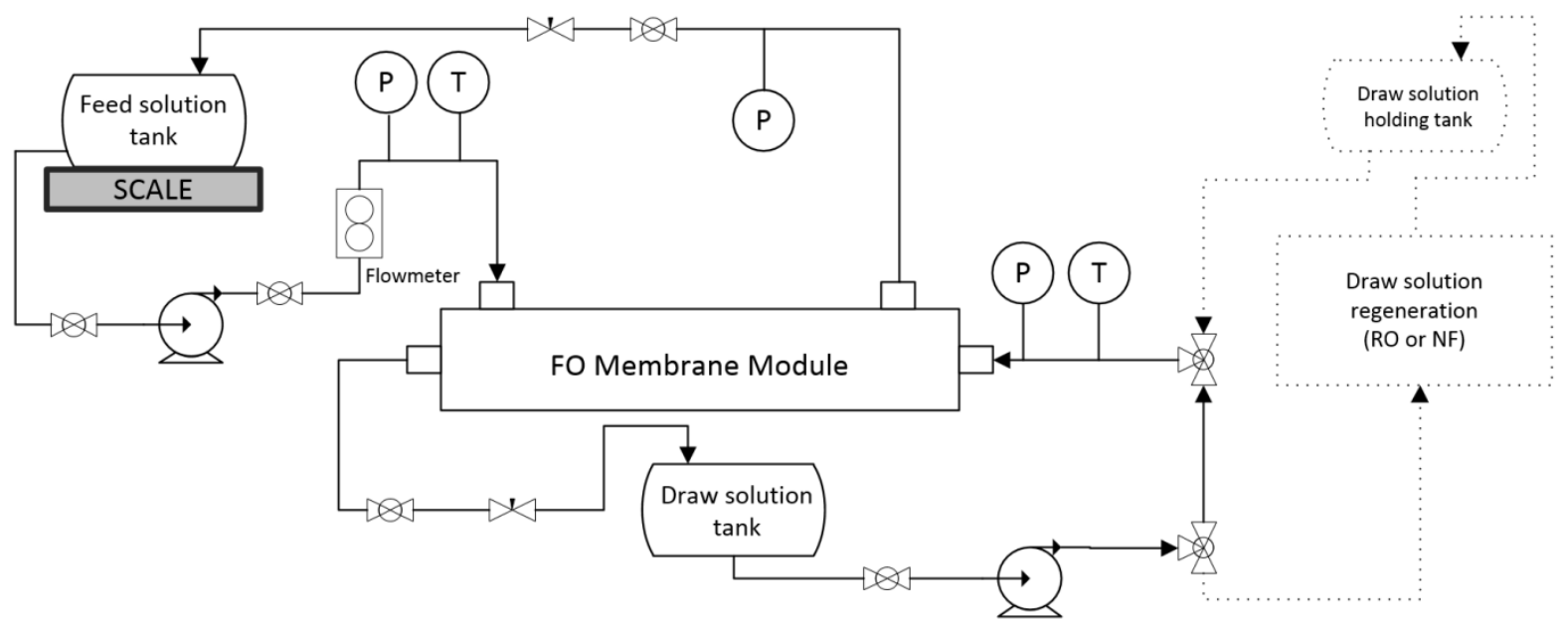

Figure 2: Schematic of the forward osmosis pilot plant. Flows of feed and draw solutions are through the side and end ports, respectively. The draw solution holding tank and regeneration unit, indicated by the dashed lines, were not in operation for the duration of the experiments.

\subsection{Performance evaluation}

The transmembrane pressure (TMP, bar) was calculated [21] as the average hydraulic pressure difference between the feed solution side and the draw solution side:

The total net driving force is defined as:

where $\Delta \pi$ is the osmotic pressure difference between the feed and the draw solution.

The osmotic pressure $(\pi)$ of an aqueous solution was determined by:

$\Pi=m \rho R T$

Equation 3

where $m$ is the solution osmolality $(\mathrm{mmol} / \mathrm{kg})$ measured by a vapor pressure osmometer (VAPRO ${ }^{\oplus}$ vapor pressure osmometer, Wescor Inc., USA), $\rho$ the density of the solution, $R$ the ideal gas constant and $T$ the absolute temperature.

136 The concentration factor (CF) of the feed was calculated by:

$137 \quad C F=\frac{M_{0}}{M_{t}}$

Equation 4 
where $M_{0}$ is the initial mass of the feed and $M_{t}$ the mass of the feed at a given time during the concentration process.

Water flux through the membrane $\left(J_{w}\right.$, litres $/ \mathrm{m}^{2}$.h or $\left.\mathrm{LMH}\right)$ was determined by:

$J_{w}=\frac{\Delta M}{\rho A_{m} \Delta t}$

Equation 5

where $\Delta M$ is the mass difference within a time internal $(\Delta t)$ and $A_{m}$ the total active membrane area (i.e. $24 \mathrm{~m}^{2}$ for two FTSH2O FO elements). The density of milk and whey was taken as $1.03 \mathrm{~g} / \mathrm{ml}$ [22]. For membrane module characterisation, water was pumped through both side of the membranes. The average pressure of the feed solution side was varied from 0.5-2.8 bar in a random order. The pressure of the draw solution side was kept below 0.25 bar. The water permeability coefficient $(A)$ was hence estimated using:

$A=\frac{J_{w}}{T M P}$

Equation 6

The reverse salt flux $\left(J_{S}, \mathrm{GMH}\right)$ was calculated using:

$J_{S}=\frac{\text { mass of salt transferred to feed }}{A_{m} \Delta t}$

Equation 7

The rejection of salt from the draw solution $\left(R_{s, \text { draw }}\right)$ was calculated by:
$R_{s, \text { draw }}=\left(1-\frac{\text { mass of salt transferred to feed }}{\text { mass water removed }}\right) \times 100$
Equation 8

The specific energy consumption per unit mass of water removed from the feed, $E_{s p}$, $(\mathrm{kWh} / \mathrm{t}$ water removed) was estimated based on the electric power, $P_{e}$, consumed by the feed and draw solution pumps:

$E_{s p}=\frac{P_{e} t}{M_{0}-M_{t}}$

Equation 9

where $t$ is the time taken to reduce the mass of the feed solution from $M_{0}$ to $M_{t}$. The electric power was determined from the corresponding pump curves specified by the pump manufacturer.

\subsection{Membrane cleaning}

The FO membranes can become fouled by microorganisms, protein deposits and mineral scale built up during operation. Other workers have observed that this fouling can be removed by hydraulic washing without chemical addition, due to the absence of high hydraulic pressure in forward osmosis 
operations [23, 24]. More extensive membrane cleaning usually requires acid solutions to remove inorganic deposits from the membrane and alkaline solutions to remove organic fouling. The narrow $\mathrm{pH}$ tolerance of cellulose acetate-based membranes $(\mathrm{pH} 3-8)$, however, has led to challenges for developing an appropriate cleaning strategy [20].

In this work, the use of an enzyme based solution was therefore considered as an alternative to alkali cleaning, as it operates at neutral $\mathrm{pH}$ and thus will not affect membrane integrity over multiple cleaning cycles. The pilot plant was cleaned-in-place (CIP) at $35 \pm 3^{\circ} \mathrm{C}$ after processing milk and whey samples. The CIP was performed at a volumetric flowrate $20 \%$ higher than the flowrate during milk and whey concentration. The cleaning process involved three steps: (1) circulation of citric (pH 3.33.6) for $30 \mathrm{~min}$, to remove any mineral scale; (2) circulation of an enzyme based solution ( $\mathrm{pH} 7.3 \pm 0.2$ ) for $45 \mathrm{~min}$, to remove any adsorbed protein and lipid material from the membranes; and (3) circulation of citric acid under the same conditions as in Step (1), to deactivate any remaining enzyme. The membranes were rinsed with water for $30 \mathrm{~min}$ prior to each step, as well as at the end of Step (3). The enzyme solution contains $0.07 \% \mathrm{v} / \mathrm{v}$ and $0.04 \% \mathrm{v} / \mathrm{v}$ of the Holchem enzyme blend (for the feed and draw solution sides, respectively) in $0.1 \% \mathrm{v} / \mathrm{v}$ neutral buffer. The cleaning protocol was implemented after each filtration experiment. The effectiveness of CIP was assessed by water flux experiments, which were performed after membrane cleaning and before milk experiments.

\subsection{Sample analysis}

The total solids and total ash contents were determined as per Australian Standards AS 2003.1.1 and AS 2003.1.5. The whey and milk samples were weighed before drying at $110^{\circ} \mathrm{C}$ for more than 12 hours in a fan forced oven to evaporate all moisture. After weighing, the dried samples were further charred in a furnace at $650^{\circ} \mathrm{C}$ for at least 12 hours until the samples turned white. The organic content was determined by subtracting the total ash from the total solids content.

The concentration of sodium was determined using Inductively Coupled Plasma Atomic Emission Spectroscopy (ICP-OES 720ES, Varian). Lactose concentrations were determined using highperformance liquid chromatography (HPLC). An Aminex HPX-87H ion exclusion column (BIO-RAD) was used with a mobile phase of $0.009 \mathrm{~N} \mathrm{H}_{2} \mathrm{SO}_{4}$ at $0.6 \mathrm{ml} / \mathrm{min}$ and $60^{\circ} \mathrm{C}$. Lactose was detected by a Refractive Index Detector (RID). The protein content in the draw solutions was investigated using sodium dodecyl sulphate polyacrylamide gel electrophoresis (SDS-PAGE), by following the procedure described elsewhere [9]. 


\section{RESULTS AND DISCUSSION}

196

197

\subsection{Module characterisation}

The general transport properties of the CTA membranes were first characterized after the membrane module was installed. For these initial experiments, water was used on both sides of the membrane for determining the pure water flux under a range of transmembrane pressures, as described in Section 2.3. As shown in Figure 3, the water flux increases from $0.7 \times 10^{-7} \mathrm{~m} / \mathrm{s}$ to $3.2 \times 10^{-7} \mathrm{~m} / \mathrm{s}$ (equivalent to $0.25 \mathrm{LMH}$ to $1.2 \mathrm{LMH}$ ) as the TMP changes from 0.5 bar to 2.5 bar. The water permeability coefficient $\left(1.38 \pm 0.04 \times 10^{-7} \mathrm{~m} / \mathrm{s} \cdot \mathrm{bar}\right.$ is in the same order of magnitude as has been reported in the literature $[25,26]$ for cellulose acetate based FO membranes.

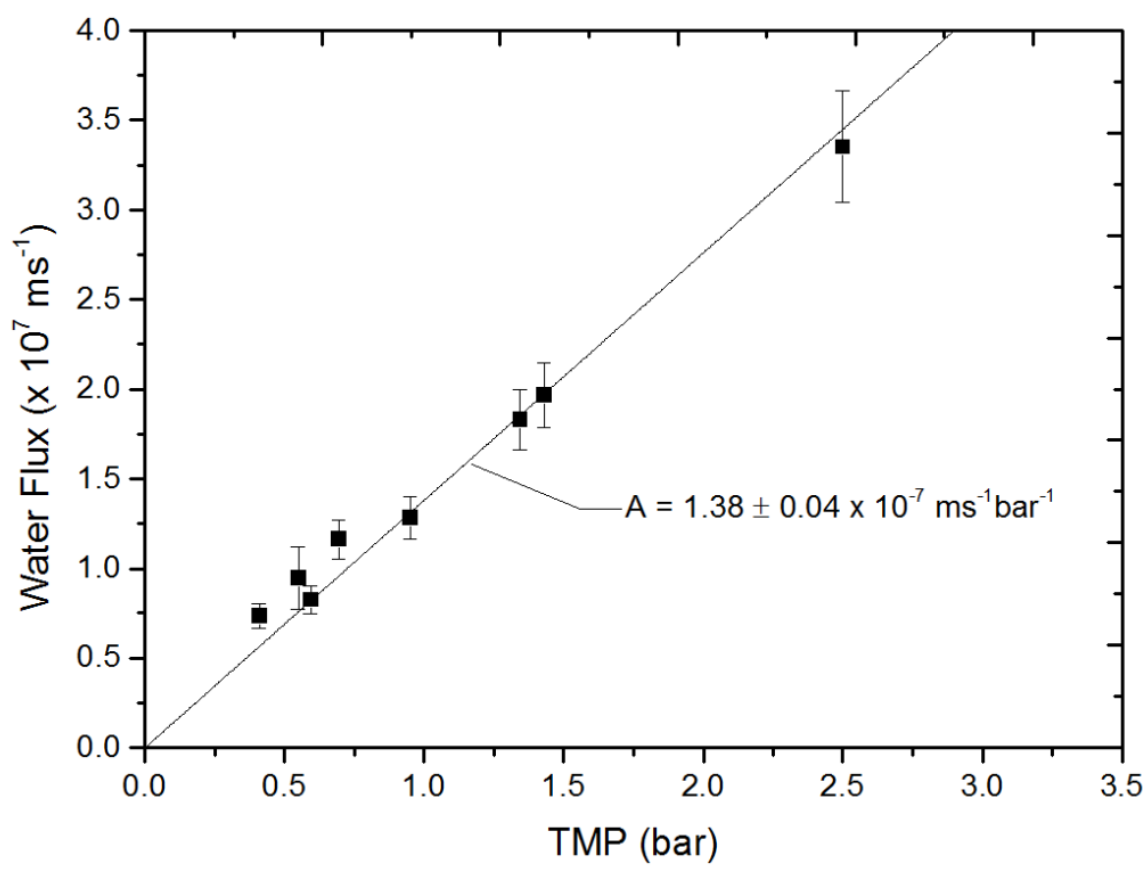

Figure 3: Water flux as a function of average transmembrane pressure when water was used on both sides of the membrane as part of initial characterization experiments (average feed pressure: 0.5- 2.8 bar; average draw solution side pressure: $<0.25$ bar).

To further characterise the membrane performance, the pilot plant was then operated in single pass mode where the feed and draw solutions were not returned to the tanks. The draw solution concentration was $35.8 \pm 0.2 \mathrm{~g} / \mathrm{L} \mathrm{NaCl}$, equivalent to an osmotic pressure of $28.2 \pm 0.2$ bar and typical of the average value anticipated during later experiments in recirculating mode. As seen in Table 3Error! Reference source not found., both the water and reverse salt fluxes are slightly higher at higher volumetric flowrates. The rejection of $\mathrm{NaCl}$ from the draw solution is $\sim 99.96 \%$, which is consistent with the information provided by the membrane manufacturer (Table 2). The specific 
reverse solute flux is lower than, but of the same order of magnitude as that reported previously for a HTI CTA FO membrane module [15]. These results confirm that the FO membrane module was successfully assembled on site while preserving the integrity of the membranes.

Table 3: Membrane performance using water as the feed while keeping the draw solution concentration constant ( $\mathrm{NaCl}: 35.8 \pm 0.2 \mathrm{~g} / \mathrm{L}$ ( $\pi=28.2 \pm 0.2$ bar). The pilot plant was operated in a single pass mode.

\begin{tabular}{|c|c|c|c|c|c|}
\hline $\begin{array}{c}\text { Feed solution } \\
\text { flowrate }\end{array}$ & $\begin{array}{c}\text { Draw solution } \\
\text { flowrate }\end{array}$ & $\begin{array}{c}\text { Flux } \\
\text { (Jw) }\end{array}$ & $\begin{array}{c}\text { Reverse NaCl } \\
\text { flux (Js) }\end{array}$ & $\begin{array}{c}\text { Specific reverse } \\
\text { solute flux (Js/Jw) }\end{array}$ & $\begin{array}{c}\text { NaCl } \\
\text { Rejection }\end{array}$ \\
\hline L/min & L/min & LMH & GMH & g/L & - \\
\hline $29.2 \pm 1.5$ & $6.2 \pm 0.1$ & $5.06 \pm 0.09$ & $1.2 \pm 0.2$ & 0.24 & $99.96 \%$ \\
\hline $45.6 \pm 2.3$ & $7.5 \pm 0.2$ & $5.45 \pm 0.08$ & $1.7 \pm 0.4$ & 0.31 & $99.97 \%$ \\
\hline
\end{tabular}

The pilot plant was next operated using pure water as the feed solution and $50 \mathrm{~g} / \mathrm{L} \mathrm{NaCl}$ as the initial draw solution concentration. A batch mode was used, where the feed and draw solutions are both recirculated back to the holding tanks. As water permeates from the feed solution through the membranes the draw solution is diluted, leading to a decreased osmotic pressure. Since the driving force declines, the water flux decreases (Figure 4). The water fluxes are $10 \%$ higher when the feed flowrate increases from $1.8 \mathrm{~m}^{3} / \mathrm{hr}$ to $2.7 \mathrm{~m}^{3} / \mathrm{hr}$ (Figure 4), due to the slight increase in average feed side pressure (from 0.65 bar to 1.5 bar).

As expected, when a $\mathrm{NaCl}$ solution $(\sim 2.3 \mathrm{~g} / \mathrm{L})$ was used in place of water as the feed, the water fluxes are further lowered, as the osmotic pressure difference across the membranes decreases (Figure 4). Further, Figure 4 presents the declining concentration and osmotic pressure of the draw solution when this $\mathrm{NaCl}$ solution was used on the feed side. 


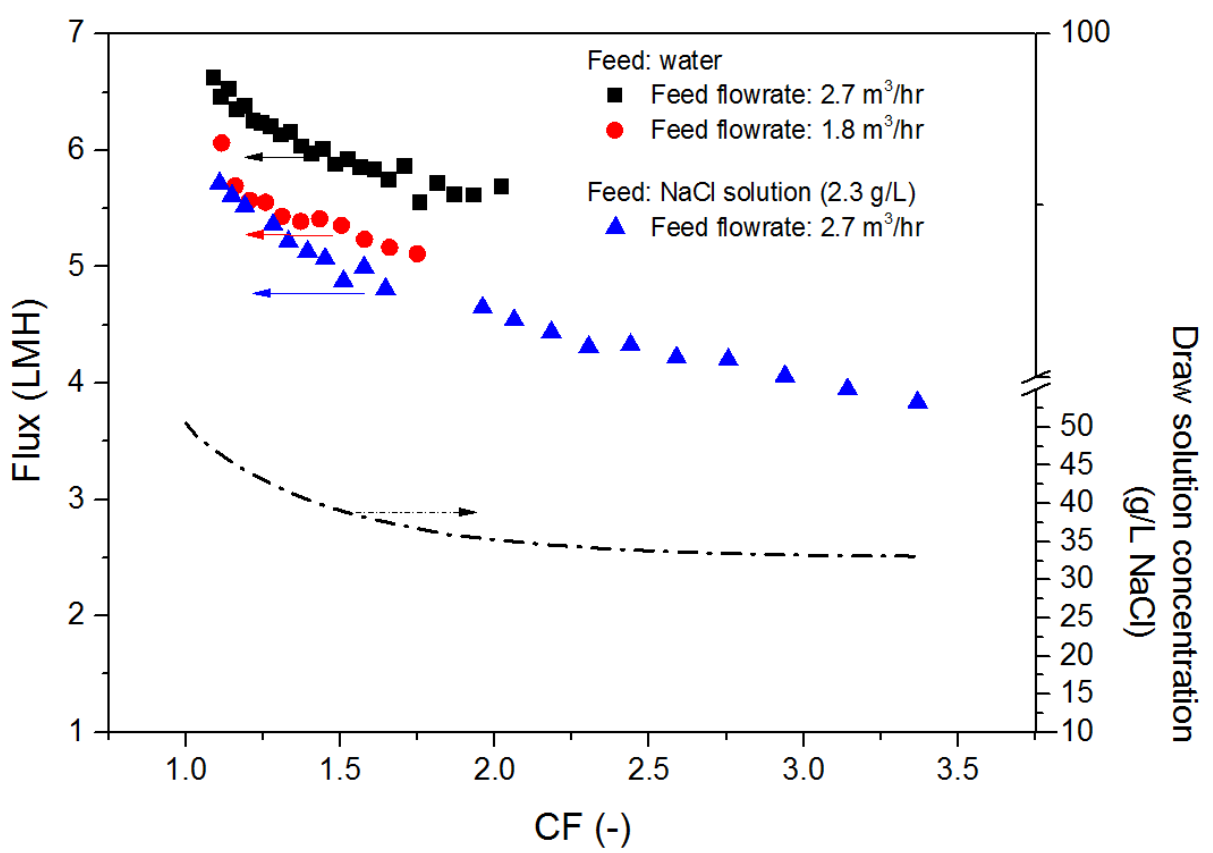

Figure 4: The water flux observed for different concentration factors of the feed (water or $2.3 \mathrm{~g} / \mathrm{L}$ $\mathrm{NaCl}$ solution), and the change of concentration of the draw solution for the case of $2.3 \mathrm{~g} / \mathrm{L} \mathrm{NaCl}$ feed. The experiment was conducted in batch mode with an initial draw solution concentration of $50 \mathrm{~g} / \mathrm{L}$. (At $2.7 \mathrm{~m}^{3} / \mathrm{hr}$ : volume of FS $=140 \mathrm{~L}$, volume of $\mathrm{DS}=170 \mathrm{~L}$; at $1.8 \mathrm{~m}^{3} / \mathrm{hr}$ : volume of $\mathrm{FS}=110 \mathrm{~L}$, volume of $\mathrm{DS}=160 \mathrm{~L}$ )

\subsection{Skim milk experiments - the effect of pressure}

Having characterized the membrane module, experiments commenced with skim milk as the feed and $50 \mathrm{~g} / \mathrm{L} \mathrm{NaCl}$ as the initial draw solution. Three experiments were initially completed to determine the effect of changing the total driving force $\left(\Delta \boldsymbol{P}_{n e t}\right)$, either by changing the transmembrane pressure difference (TMP) or the osmotic pressure difference through a change in the draw solution concentration $(\Delta \pi)$ (see Equation 2 and Table 4).

Increasing the transmembrane pressure from 0.9 to 2.2 bar, while maintaining a constant osmotic pressure difference (SM1 to SM2) makes a clear improvement in water flux when skim milk is concentrated (Figure 5). While the water flux improves in this pressure assisted osmosis (PAO) mode, the increased water flux will reduce the effective draw solution concentration at the membrane interface, reducing the contribution of this draw solution to the overall osmotic driving force.

Conversely, increasing the osmotic pressure driving force by $\sim 6$ bar by increasing the initial draw solution concentration (SM1 to SM3), whilst maintaining the transmembrane pressure at 0.9 bar causes a smaller enhancement in water flux (Figure 5). This is due to the effect of internal concentration polarisation. In these elements, the membrane support layer is exposed to the draw 
solution. The $\mathrm{NaCl}$ concentration within this support layer is effectively diluted by the flux of water permeating from the feed solution. Therefore, the effective change in the osmotic pressure difference between the draw and feed solution sides of the active layer is much less than $\sim 6$ bar. It can be seen that a direct increase of the feed side pressure (the PAO mode) has a much greater impact on membrane performance, compared to a similar increase of osmotic pressure (i.e. salt concentration) in the draw solution.

Table 4: The initial conditions and the estimated net driving force for the concentration of skim milk.

\begin{tabular}{|c|c|c|c|c|c|}
\hline \multirow{2}{*}{ Run } & $\begin{array}{c}\text { NaCl concentration } \\
\text { in draw solution }\end{array}$ & TMP & $\Delta \pi$ & $\Delta P_{\text {net }}$ & $\begin{array}{c}\text { Initial } \\
\text { water flux }\end{array}$ \\
\cline { 2 - 6 } & $\mathrm{g} / \mathrm{L}$ & bar & bar & bar & LMH \\
\hline SM1 & 48.0 & 0.9 & 30.1 & 31.0 & 4.3 \\
\hline SM2 & 48.5 & 2.2 & 30.6 & 32.8 & 5.0 \\
\hline SM3 & 54.7 & 0.9 & 35.7 & 36.5 & 4.7 \\
\hline
\end{tabular}

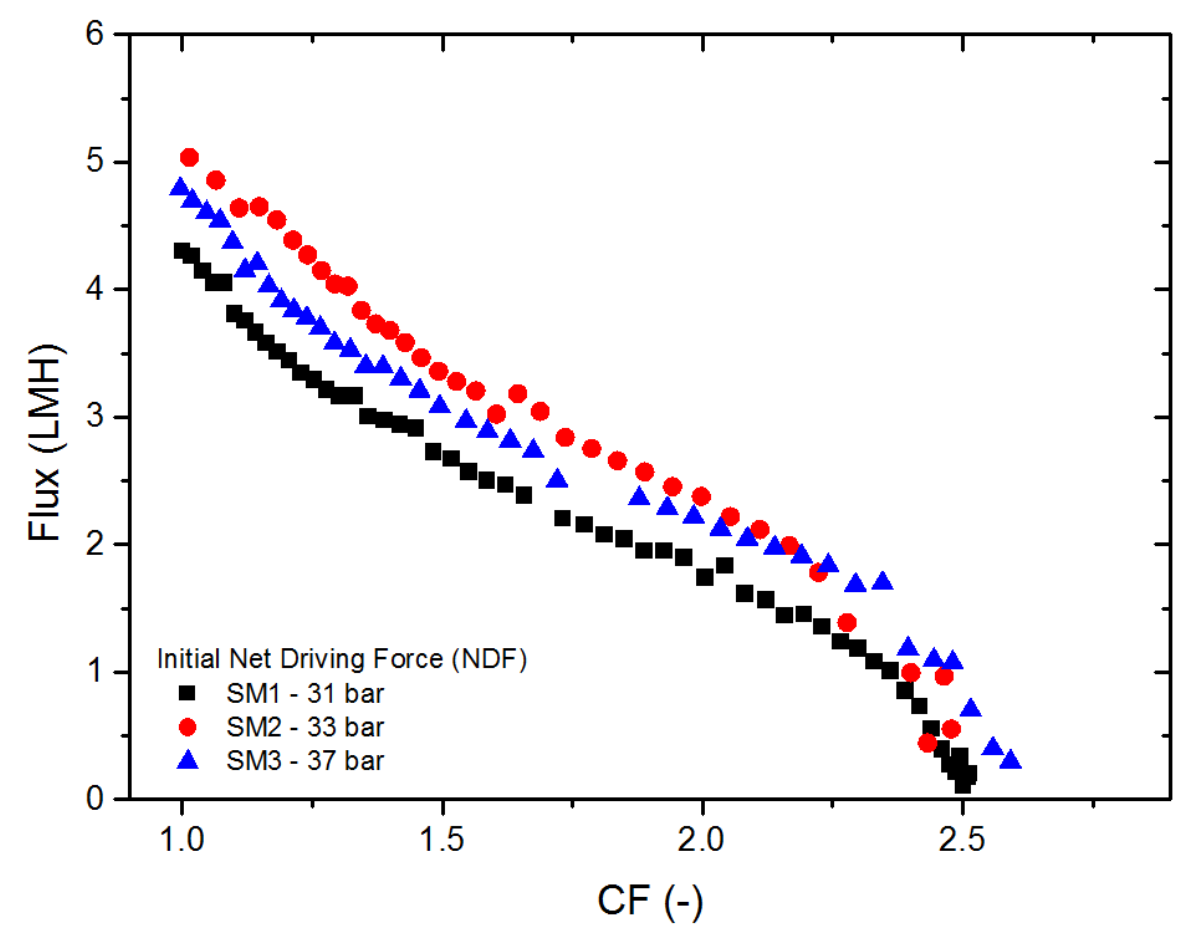

Figure 5: Water flux observed for different concentration factors of skim milk (feed solution) with different initial net driving force. The average transmembrane pressure was varied from 0.9 bar to 2.2 bar, while the osmotic pressure increased from 30 bar to 36 bar, as summarized in Table 4. (Volume of $\mathrm{FS}=140 \mathrm{~L}$, volume of $\mathrm{DS}=160 \mathrm{~L}$ ) 


\subsection{Skim milk experiments - the effect of temperature}

277 The effect of operating temperature on the membrane performance was investigated in experiments 278 with skim milk at an initial feed temperature of $16.5^{\circ} \mathrm{C}$ or $9.3^{\circ} \mathrm{C}$. The draw solution was at room 279 temperature $\left(18 \pm 2^{\circ} \mathrm{C}\right)$. Since temperature control was not in place, the temperature of the feed 280 solution for the cold run increases as the skim milk is concentrated (Figure 6). This is due to the transfer 281 of heat between the feed and draw solutions through the membranes, as well as the heat generated by the feed pump. For concentration factors below 1.3, it is obvious that the water flux is lower in the cold run than that in the room temperature run (Figure 6). As the temperature of the feed solution increases beyond $14{ }^{\circ} \mathrm{C}$ during operation, there is little difference in water flux between the two runs. Comparing the initial water flux $\left(4.5 \mathrm{LMH}\right.$ at $16.5^{\circ} \mathrm{C}$ versus $3.9 \mathrm{LMH}$ at $\left.9.3^{\circ} \mathrm{C}\right)$, it is anticipated that a $13 \%$ decrease in water flux could have been observed if the temperature of the feed solution was maintained at $\sim 9^{\circ} \mathrm{C}$.

288

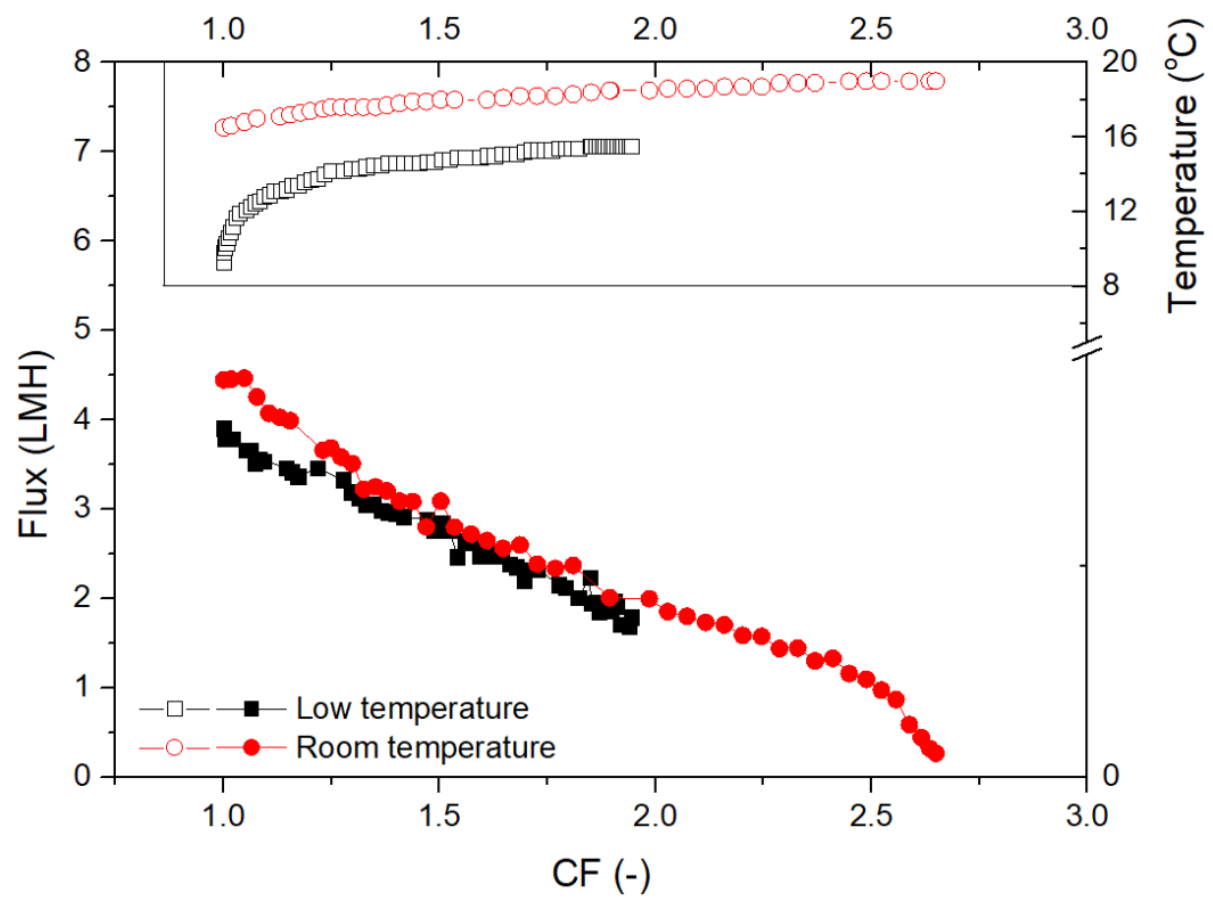

Figure 6: Water flux and operating temperature observed for various concentration factors during the concentration of skim milk (TMP: $1.0 \pm 0.1 \mathrm{bar}$, initial draw solution concentration: $48 \pm 1 \mathrm{~g} / \mathrm{L}$ ). (Volume of $\mathrm{FS}=140 \mathrm{~L}$, volume of $\mathrm{DS}=160 \mathrm{~L}$ ) 


\subsection{Foaming and cleaning}

296 During the concentration of skim milk and whey, it is expected that only water permeates through the

297 membranes, retaining all the constituents in the feed stream. However, foaming was observed in the 298 draw solution as the dairy solution was concentrated (Figure 7). Foaming in an agitated solution is an 299 indication of the presence of hydrophobic matter, probably organic in nature [27]. SDS-PAGE analysis 300 of the draw solution showed that no proteins larger than 6,000 Da were present in the draw solution. 301 This confirms the integrity of the membrane module and that there is no leakage of feed solution 302 through the fittings and seals. The foaming effect observed in the draw solution is instead likely to be 303 caused by smaller molecular weight organic species that permeate through the FO membranes. The 304 lactose flux from the feed to the draw solution was determined to be $10 \pm 1 \mathrm{mmol} / \mathrm{m}^{2} \mathrm{hr}\left(3 \mathrm{~g} / \mathrm{m}^{2} \mathrm{hr}\right)$, 305 suggesting that around half of the organic matter permeating to the draw solution is lactose. The remaining content could include organic acids, such as citrate or lactate, casein macropeptides, or non-protein nitrogenous compounds such as urea. Hancock et al. [28] found that trace organic compounds with a molecular weight ranging from 150 - 320 Da are not entirely rejected by CTA forward osmosis membranes. For dairy applications, it was also reported by Seker et al. [7] that total organic carbon is detected in the draw solution when concentrating raw whey using cellulose acetate membranes. In large scale operations, foaming induced by organic compounds may result in undesired fouling issues if the draw solution needs to be regenerated using reverse osmosis.

Figure 7: The appearance of the draw solution before (a) and after (b) a typical run of skim milk concentration, illustrating the appearance of foaming.

The total organic content in both the feed and draw solution tanks during the concentration of skim milk is presented in Figure 8. This was determined from the samples taken from the feed tank. It can be seen that a decrease $(\sim 1.2 \mathrm{~kg})$ in the mass of organic matter in the feed tank occurs, whereas the 
gain of organic matter in the draw solution tank (as described above) is less than $0.3 \mathrm{~kg}$. The 'missing' mass from the tanks must remain within the membrane module, as the circulation volume including the volume of piping and dead volume in the system was already accounted for in the calculations. Assuming that the 'missing' mass of organic matter is distributed evenly across the entire membrane area, $\sim 40 \mathrm{~g} / \mathrm{m}^{2}$ is retained within the membrane elements by the end of the experiment. However, a water flux measurement after a simple water rinse of the membrane results in only a small flux decline of 5-8\% (see Figure 10), significantly less than would occur in equivalent experiments using pressure driven membrane filtration. This suggests that the fouling associated with the bulk of this retained organic matter is reversible.

333

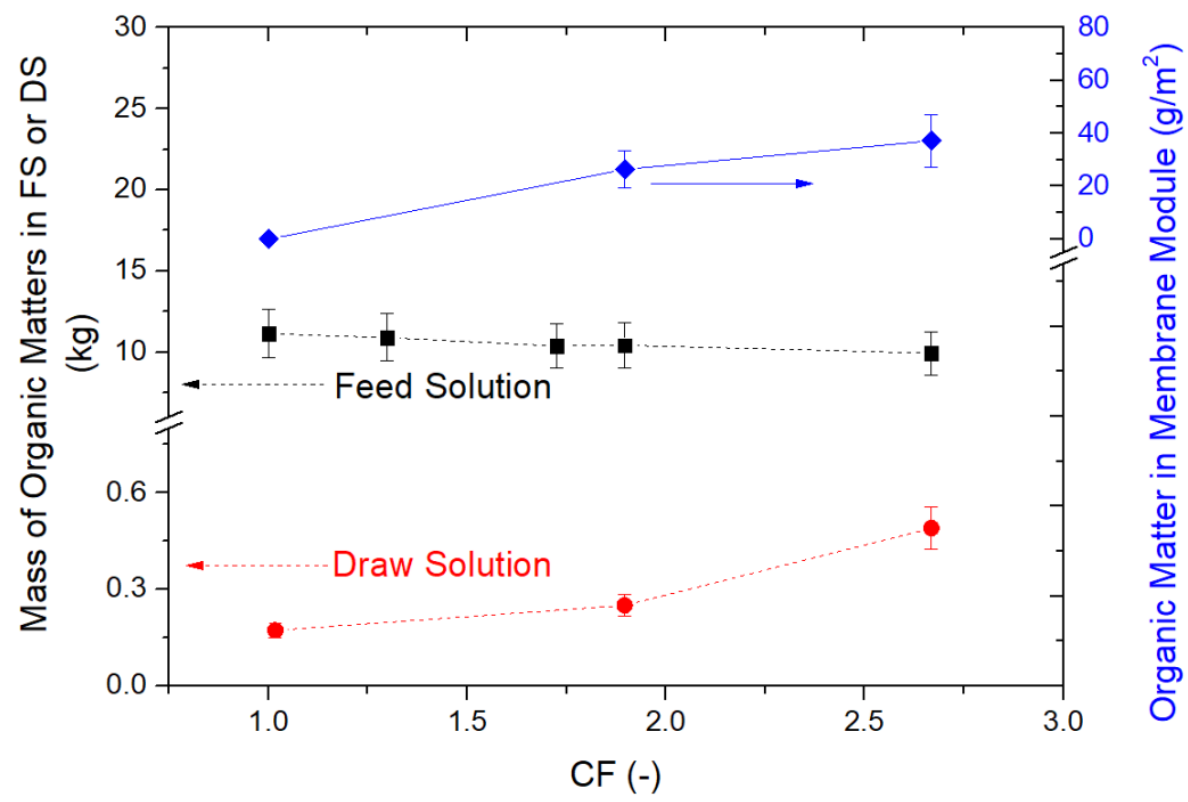

Figure 8: The mass of organic matter in the feed solution ( $\bullet$ ) and draw solution ( $\bullet$ ), and the mass of organic matter retained in the membrane module $(\$)$ during the concentration of skim milk (for the experiment conducted at room temperature shown in Figure 6). 


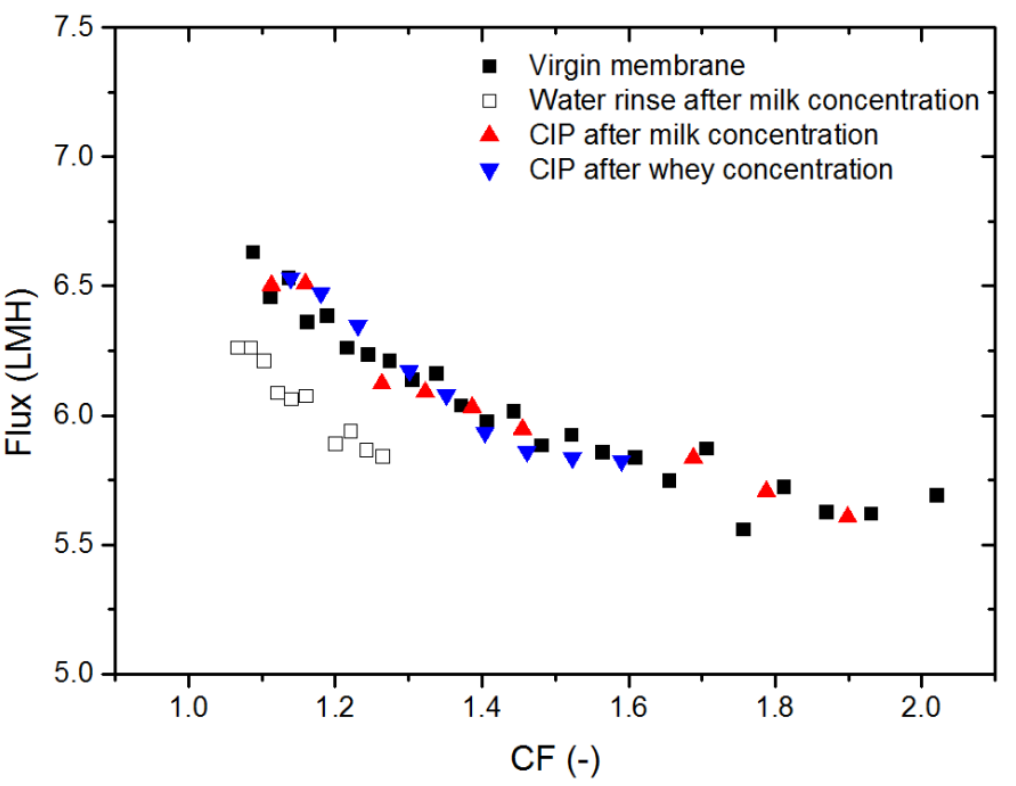

Figure 9: Water flux observed over different concentrations factors in a batch operation for the virgin 345 membranes, the membranes after milk concentration followed by a water rinse and the membranes after milk or whey concentration followed by a three step CIP procedure. Water was used as the feed and an $\mathrm{NaCl}$ solution of $48 \pm 1 \mathrm{~g} / \mathrm{L}$ was as the draw solution. (Volume of $\mathrm{FS}=140 \mathrm{~L}$, volume of DS $=160$ 348 L).

\subsection{Concentration of whey}

351 Two batches of fresh whey samples were also processed using an initial draw solution ( $\mathrm{NaCl})$ of $48 \pm$ $3521 \mathrm{~g} / \mathrm{L}$ and a TMP of $1.0 \pm 0.1$ bar. The main difference between the two batches of whey is the ash 353 content, which leads to a higher conductivity and osmolarity in Whey Sample A (Table 1). As shown in 354 Figure 10, the water flux during the concentration process is slightly lower for Whey Sample A because of its higher osmotic pressure compared to Whey Sample B. The protein content and osmolarity are both higher in skim milk than that in Whey Sample B but the water flux during skim milk concentration is generally higher, especially at high concentration factors. This is probably due to the lower fat content in the skim milk compared to the whey sample $(0.1 \mathrm{~g} / 100 \mathrm{~g}$ vs. $0.3 \mathrm{~g} / 100 \mathrm{~g})$. The high concentration of fat within the boundary layer on the surface of the membranes could act as an extra mass transfer resistance to water permeation. Although the concentration factors achieved are similar between skim milk and Whey Sample B, the total solids concentrations are significantly different (Figure 10). Without draw solution regeneration, skim milk and Whey Sample B can be concentrated from $8.0 \mathrm{wt} \%$ to $>20 \mathrm{wt} \%$ and from $5.9 \mathrm{wt} \%$ to $>13 \mathrm{wt} \%$, respectively, using $\sim 48 \pm 1 \mathrm{~g} / \mathrm{L}$ of NaCl as the draw solution. The composition of the concentrated skim milk and Whey Samples B is presented in Table 5. Comparing the fresh and the concentrated samples on a dry basis, it can be seen that the product composition is hardly affected by the forward osmosis process. The changes in protein, fat 
367 and lactose are marginal and the sodium concentration increased only by $\sim 150 \mathrm{mg} / 100 \mathrm{~g}$ and $\sim 90$ $368 \mathrm{mg} / 100 \mathrm{~g}$ for skim milk and Whey Sample B, respectively (Table 5). There is no information readily 369 available on a regulatory limit to the sodium content in milk and whey powder, so it is unclear whether 370 this increase would be acceptable for commercial products.

371 Under the operating conditions used for this pilot scale study and from the initial volume of feed and 372 draw solutions, it can be estimated that it requires almost the same amount of draw solution to 373 concentrate a particular volume of feed solution by $\sim 2.5$ times. To achieve this concentration factor, $374<8.5 \mathrm{kWh}$ and $<10 \mathrm{kWh}$ of electrical energy is required to remove one tonne of water for skim milk 375 and Whey Sample B, respectively, as shown in Figure 11. It is reported that between 80 and $330 \mathrm{~kg}$ of 376 steam is needed for removing one tonne of water from milk using vacuum evaporation processes 377 [29], which is equivalent to between 17 and $70 \mathrm{kWh}$ of electrical energy, given a typical efficiency of 378 thermal to electrical conversion efficiency of $33 \%$. The energy consumption for reverse osmosis is less 379 (9-20 kWh/t water removed) [30, 31].

380 It can be seen that the forward osmosis step is more energy efficient than reverse osmosis, because 381 high hydraulic pressures are not required. This means that forward osmosis may be considered as an 382 effective and efficient process for pre-concentration of dairy streams, if an abundant source of brine 383 can be identified in a given dairy processing facility so that regeneration of draw solution is not needed. 


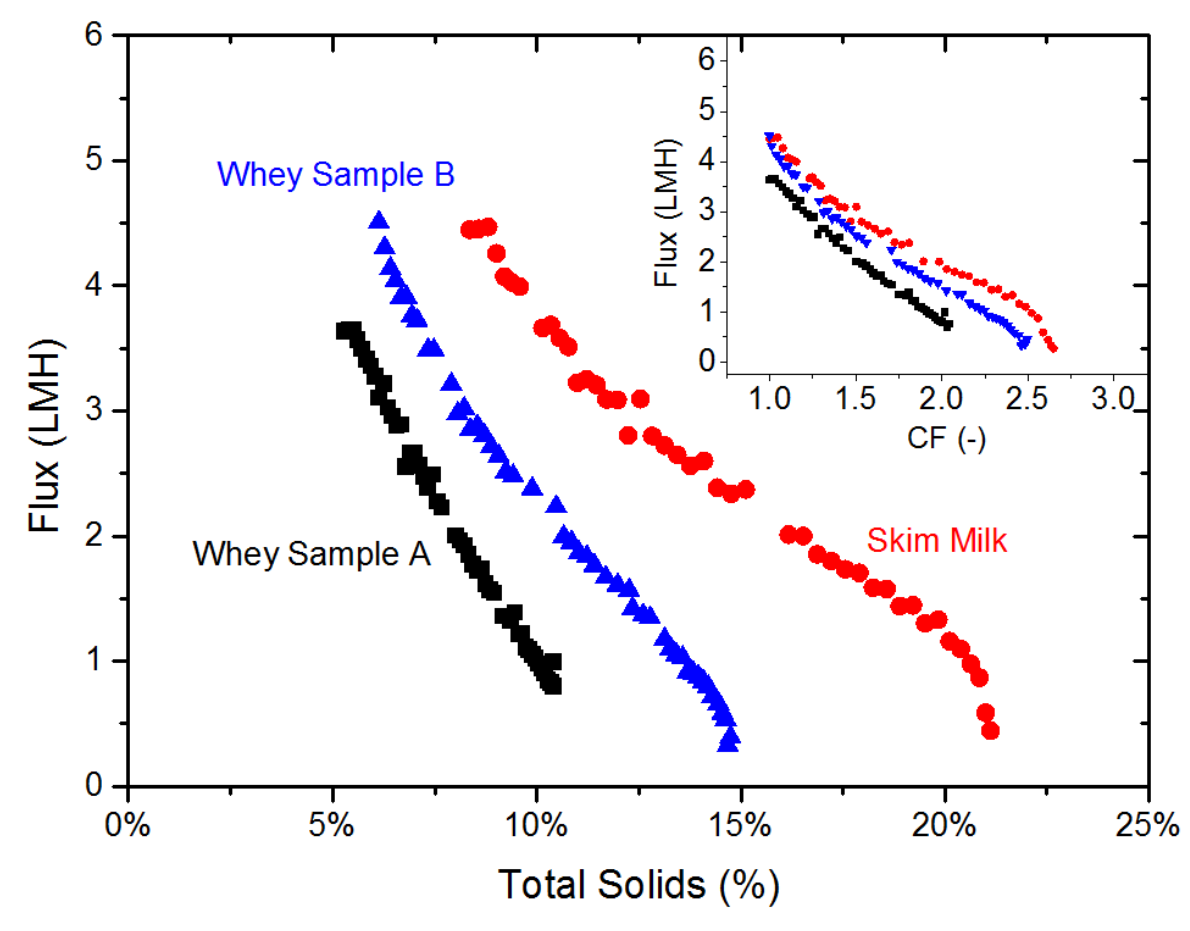

386 Figure 10: Water flux observed for different total solids concentrations for skim milk( $\bullet)$, Whey Sample 387 A ( $\square)$ and Whey Sample B $(\diamond)$ tested by the FO pilot plant. All experiments were conducted at room 388 temperature in batch mode, with an initial draw solution $(\mathrm{NaCl})$ of $48 \pm 1 \mathrm{~g} / \mathrm{L}$ and a TMP of $1.0 \pm 0.1$ 389 bar. Insert: Water flux is plotted against concentration factor for all the dairy samples. (Volume of FS $390=140 \mathrm{~L}$, volume of $\mathrm{DS}=160 \mathrm{~L}$ )

Table 5: The composition of the fresh and concentrated samples of milk and whey.

\begin{tabular}{|c|c|c|c|c|c|}
\hline \multirow{2}{*}{} & \multirow{2}{*}{ Unit } & \multicolumn{2}{|c|}{ Skim Milk (SM3) } & \multicolumn{2}{c|}{ Whey Sample B } \\
\cline { 3 - 6 } & & Fresh & FO Concentrate & Fresh & FO Concentrate \\
\hline \multicolumn{5}{|c|}{ Wet Basis } \\
\hline TS & wt\% & 8.0 & 22 & 5.9 & 15 \\
\hline Ash & wt\% & 0.7 & 1.9 & 0.55 & 1.3 \\
\hline Osmolarity & $\mathrm{mmol} / \mathrm{kg}$ & 335 & 1034 & 293 & 989 \\
\hline \multicolumn{5}{|c|}{ Dry basis } \\
\hline Protein & $\mathrm{g} / 100 \mathrm{~g}$ & 39.7 & 37.5 & 15.9 & 15.7 \\
\hline Fat & $\mathrm{g} / 100 \mathrm{~g}$ & 1.2 & 0.9 & 5.1 & 4.6 \\
\hline Lactose & $\mathrm{g} / 100 \mathrm{~g}$ & 46.4 & 48.4 & 72.9 & 66.8 \\
\hline Na & $\mathrm{mg} / 100 \mathrm{~g}$ & 454 & 602 & 693 & 782 \\
\hline
\end{tabular}




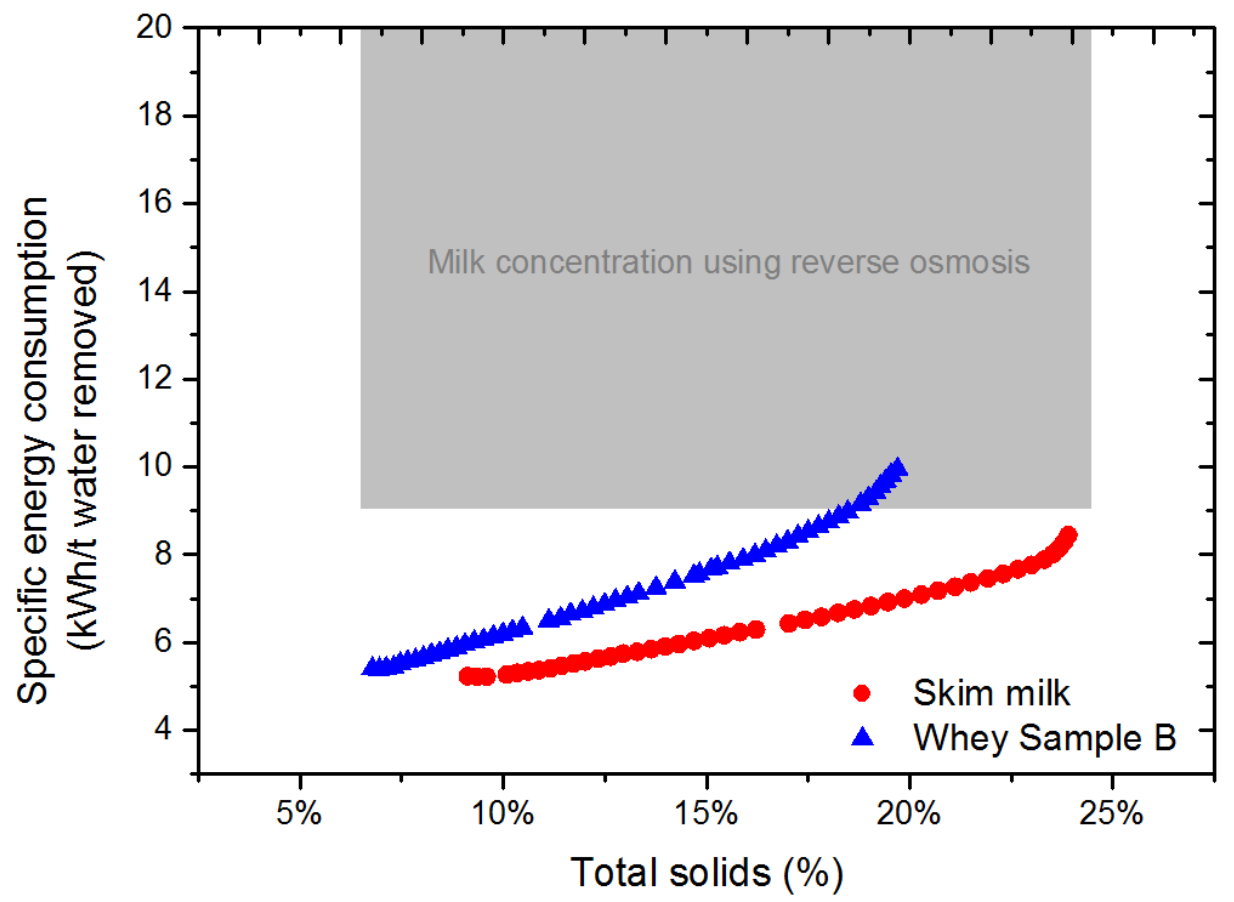

Figure 11: Specific electrical energy consumption for the concentration of skim milk (SM2) and Whey Sample B over a range of total solids concentrations. The grey area represents the typical range of energy consumption reported for milk concentration using reverse osmosis [30, 31].

\section{CONCLUSION}

The concentration of skim milk and whey by forward osmosis was investigated in a pilot plant with an active membrane area of $24 \mathrm{~m}^{2}$. The pilot plant was operated in batch mode where the draw solution $(48-57 \mathrm{~g} / \mathrm{L}$ of $\mathrm{NaCl})$ was diluted with water removed from the feed solution. An increase of the feed side pressure (i.e. transmembrane pressure) was found to be more effective in enhancing water flux, compared to a similar increase in the draw solution concentration (i.e. osmotic pressure driving force). A concentration factor of $\sim 2.5$ was achieved in the forward osmosis concentrate, resulting in a total solids concentration of $\sim 21 \mathrm{wt} \%$ and $15 \mathrm{wt} \%$ for the skim milk and whey sample, respectively. The water flux started at $\sim 5 \mathrm{LMH}$ and declined to below $0.5 \mathrm{LMH}$ as the osmotic driving force was diminishing.

409 The pilot scale study provides essential quantification of sodium migration into FO concentrated dairy 410 products for regulators, dairy processors and membrane engineers. Migration of small organic molecules was also observed, which caused foaming in the draw solution during the concentration process. The study showed that fouling of these cellulose triacetate membranes is small for the level of concentration achieved. Given the narrow operating range of $\mathrm{pH}$ for the CTA membranes, the cleaning protocol used in this work was able to completely restore the membrane performance after fouling. The specific energy required to remove one tonne of water for milk and whey concentration 
could be much lower than that required by reverse osmosis, provided that the regeneration of draw solution can be avoided by provision of a suitable salty whey or brine stream as a draw stream. This study demonstrates the potential feasibility of FO and application of FO at larger scale.

\section{ACKNOWLEDGEMENTS}

This research was supported under The Australian Research Council's Industrial Transformation Research Program (ITRP) funding scheme (project number IH120100005). The ARC Dairy Innovation Hub is a collaboration between The University of Melbourne, The University of Queensland and Dairy Innovation Australia Ltd. Dr. George Chen would like to acknowledge the financial support by the Victorian Government, Australia, through a Victoria Fellowship. The authors would like to thank High Weald Dairy (UK) for providing the whey samples used in this work, as well as Holchem Laboratories Ltd (UK) for the thoughtful discussions regarding CIP strategies and the provision of cleaning chemicals.

\section{REFERENCES}

[1] P. Schuck, R. Jeantet, G. Tanguy, S. Méjean, A. Gac, T. Lefebvre, E. Labussière, C. Martineau, Energy Consumption in the Processing of Dairy and Feed Powders by Evaporation and Drying, Drying Technol., 33 (2015) 176-184.

[2] A.S. Moon, M. Lee, Energy Consumption in Forward Osmosis Desalination Compared to other Desalination Techniques, International Journal of Chemical, Molecular, Nuclear, Materials and Metallurgical Engineering, 65 (2012) 421 - 423.

[3] C. Aydiner, U. Sen, S. Topcu, D. Ekinci, A.D. Altinay, D.Y. Koseoglu-Imer, B. Keskinler, Technoeconomic viability of innovative membrane systems in water and mass recovery from dairy wastewater, J. Membr. Sci., 458 (2014) 66-75.

[4] C. Aydiner, U. Sen, S. Topcu, D. Sesli, D. Ekinci, A.D. Altınay, B. Ozbey, D.Y. Koseoglu-Imer, B. Keskinler, Techno-economic investigation of water recovery and whey powder production from whey using UF/RO and FO/RO integrated membrane systems, Desalin. Water Treat., 52 (2014) 123133.

[5] C. Aydiner, S. Topcu, C. Tortop, F. Kuvvet, D. Ekinci, N. Dizge, B. Keskinler, A novel implementation of water recovery from whey: "forward-reverse osmosis" integrated membrane system, Desalin. Water Treat., 51 (2013) 786-799.

[6] M. Seker, E. Buyuksari, S. Topcu, D.S. Babaoglu, D. Celebi, B. Keskinler, C. Aydiner, Effect of pretreatment and membrane orientation on fluxes for concentration of whey with high foulants by using NH3/CO2 in forward osmosis, Bioresour. Technol., 243 (2017) 237-246.

[7] M. Seker, E. Buyuksari, S. Topcu, D. Sesli, D. Celebi, B. Keskinler, C. Aydiner, Effect of process parameters on flux for whey concentration with $\mathrm{NH} 3 / \mathrm{CO} 2$ in forward osmosis, Food Bioprod. Process., 105 (2017) 64-76.

[8] Y.-N. Wang, R. Wang, W. Li, C.Y. Tang, Whey recovery using forward osmosis - Evaluating the factors limiting the flux performance, J. Membr. Sci., 533 (2017) 179-189.

[9] K. Kezia, J. Lee, M. Weeks, S. Kentish, Direct contact membrane distillation for the concentration of saline dairy effluent, Water Res., 81 (2015) 167-177.

[10] G.Q. Chen, S. Talebi, S.L. Gras, M. Weeks, S.E. Kentish, A Review of Salty Waste Stream Management in the Australian Dairy Industry J. Environ. Manage., (2018). 
[11] Modern Water to build first forward osmosis desalination plant, Pump Industry Analyst, 2011 (2011) 3.

[12] M.M. Pendergast, M.S. Nowosielski-Slepowron, J. Tracy, Going big with forward osmosis, Desalin. Water Treat., 57 (2016) 26529-26538.

[13] S. Phuntsho, J.E. Kim, M.A.H. Johir, S. Hong, Z. Li, N. Ghaffour, T. Leiknes, H.K. Shon, Fertiliser drawn forward osmosis process: Pilot-scale desalination of mine impaired water for fertigation, J. Membr. Sci., 508 (2016) 22-31.

[14] J.E. Kim, S. Phuntsho, F. Lotfi, H.K. Shon, Investigation of pilot-scale 8040 FO membrane module under different operating conditions for brackish water desalination, Desalin. Water Treat., 53 (2015) 2782-2791.

[15] J. Kim, G. Blandin, S. Phuntsho, A. Verliefde, P. Le-Clech, H. Shon, Practical considerations for operability of an 8" spiral wound forward osmosis module: Hydrodynamics, fouling behaviour and cleaning strategy, Desalination, 404 (2017) 249-258.

[16] R. Valladares Linares, Z. Li, S. Sarp, S.S. Bucs, G. Amy, J.S. Vrouwenvelder, Forward osmosis niches in seawater desalination and wastewater reuse, Water Res., 66 (2014) 122-139.

[17] R.L. McGinnis, N.T. Hancock, M.S. Nowosielski-Slepowron, G.D. McGurgan, Pilot demonstration of the $\mathrm{NH} 3 / \mathrm{CO} 2$ forward osmosis desalination process on high salinity brines, Desalination, 312 (2013) 67-74.

[18] J.-J. Qin, M.H. Oo, K.A. Kekre, B. Liberman, Development of novel backwash cleaning technique for reverse osmosis in reclamation of secondary effluent, J. Membr. Sci., 346 (2010) 8-14.

[19] Z. Wang, J. Zheng, J. Tang, X. Wang, Z. Wu, A pilot-scale forward osmosis membrane system for concentrating low-strength municipal wastewater: performance and implications, Sci. Rep., 6 (2016) 21653.

[20] L. Lv, J. Xu, B. Shan, C. Gao, Concentration performance and cleaning strategy for controlling membrane fouling during forward osmosis concentration of actual oily wastewater, J. Membr. Sci., 523 (2017) 15-23.

[21] C. Dreszer, H.C. Flemming, A. Zwijnenburg, J.C. Kruithof, J.S. Vrouwenvelder, Impact of biofilm accumulation on transmembrane and feed channel pressure drop: Effects of crossflow velocity, feed spacer and biodegradable nutrient, Water Res., 50 (2014) 200-211.

[22] P. GonzÁLez-Tello, F. Camacho, E.M. Guadix, G. LuzÓN, P.A. GonzÁLez, Density, Viscosity And Surface Tension Of Whey Protein Concentrate Solutions, J. Food Process Eng., 32 (2009) 235-247. [23] B. Mi, M. Elimelech, Organic fouling of forward osmosis membranes: Fouling reversibility and cleaning without chemical reagents, J. Membr. Sci., 348 (2010) 337-345.

[24] S. Lee, C. Boo, M. Elimelech, S. Hong, Comparison of fouling behavior in forward osmosis (FO) and reverse osmosis (RO), J. Membr. Sci., 365 (2010) 34-39.

[25] J. Ren, J.R. McCutcheon, A new commercial thin film composite membrane for forward osmosis, Desalination, 343 (2014) 187-193.

[26] K.Y. Wang, R.C. Ong, T.-S. Chung, Double-Skinned Forward Osmosis Membranes for Reducing Internal Concentration Polarization within the Porous Sublayer, Ind. Eng. Chem. Res., 49 (2010) 4824-4831.

[27] N. Ganidi, S. Tyrrel, E. Cartmell, Anaerobic digestion foaming causes - A review, Bioresour. Technol., 100 (2009) 5546-5554.

[28] N.T. Hancock, P. Xu, D.M. Heil, C. Bellona, T.Y. Cath, Comprehensive Bench- and Pilot-Scale Investigation of Trace Organic Compounds Rejection by Forward Osmosis, Environ. Sci. Technol., 45 (2011) 8483-8490.

[29] G. Bylund, M. Hellman, Dairy processing handbook, Tetra Pak Processing Systems, Lund, Sweden, 2015.

[30] G. Daufin, J.P. Escudier, H. Carrère, S. Bérot, L. Fillaudeau, M. Decloux, Recent and Emerging Applications of Membrane Processes in the Food and Dairy Industry, Food Bioprod. Process., 79 (2001) 89-102. 
[31] C. Brazinha, A. Cassano, C. Charcosset, C. Conidi, J.G. Crespo, F.P. Cuperus, S. De, E. Drioli, Y.E. Rayess, A.C.M. Franken, Integrated Membrane Operations: In the Food Production, De Gruyter, 2014.

\section{Table Captions}

Table 1: The composition of the skim milk and whey samples used in this work. Errors are standard deviations $(n=3)$.

Table 2: Properties of OsmoF2O FO membrane.

Table 3: Membrane performance using water as the feed while keeping the draw solution concentration constant ( $\mathrm{NaCl}: 35.8 \pm 0.2 \mathrm{~g} / \mathrm{L}(\pi=28.2 \pm 0.2 \mathrm{bar}$ ). The pilot plant was operated in a single pass mode.

Table 4: The initial conditions and the estimated net driving force for the concentration of skim milk. Table 5: The composition of the fresh and concentrated samples of milk and whey.

\section{Figure Captions}

Figure 1: The proposed concentration process of milk or whey by forward osmosis. A waste brine within the dairy processing plant is used as the draw solution. The black arrows indicate process flow and the blue arrow indicates the migration of water into the draw stream.

Figure 2: Schematic of the forward osmosis pilot plant. Flows of feed and draw solutions are through the side and end ports, respectively. The draw solution holding tank and regeneration unit, indicated by the dashed lines, were not in operation for the duration of the experiments.

Figure 3: Water flux as a function of average transmembrane pressure when water was used on both sides of the membrane as part of initial characterization experiments (average feed pressure: 0.52.8 bar; average draw solution side pressure: $<0.25$ bar).

Figure 4: The water flux observed for different concentration factors of the feed (water or $2.3 \mathrm{~g} / \mathrm{L}$ $\mathrm{NaCl}$ solution), and the change of concentration of the draw solution for the case of $2.3 \mathrm{~g} / \mathrm{L} \mathrm{NaCl}$ feed. The experiment was conducted in batch mode with an initial draw solution concentration of $50 \mathrm{~g} / \mathrm{L}$. (At $2.7 \mathrm{~m}^{3} / \mathrm{hr}$ : volume of FS=140 L, volume of DS = $170 \mathrm{~L}$; at $1.8 \mathrm{~m}^{3} / \mathrm{hr}$ : volume of $\mathrm{FS}=110 \mathrm{~L}$, volume of $\mathrm{DS}=160 \mathrm{~L}$ )

Figure 5: Water flux observed for different concentration factors of skim milk (feed solution) with different initial net driving force. The average transmembrane pressure was varied from 0.9 bar to 2.2 bar, while the osmotic pressure increased from 30 bar to 36 bar, as summarized in Table 4 . (Volume of $\mathrm{FS}=140 \mathrm{~L}$, volume of $\mathrm{DS}=160 \mathrm{~L}$ )

Figure 6: Water flux and operating temperature observed for various concentration factors during the concentration of skim milk (TMP: $1.0 \pm 0.1$ bar, initial draw solution concentration: $48 \pm 1 \mathrm{~g} / \mathrm{L}$ ). (Volume of FS $=140 \mathrm{~L}$, volume of $\mathrm{DS}=160 \mathrm{~L}$ )

Figure 7: The appearance of the draw solution before (a) and after (b) a typical run of skim milk concentration, illustrating the appearance of foaming.

Figure 8: The mass of organic matter in the feed solution ( $\bullet$ ) and draw solution ( $\bullet$ ), and the mass of organic matter retained in the membrane module $(\diamond)$ during the concentration of skim milk (for the experiment conducted at room temperature shown in Figure 6). 
550 Figure 9: Water flux observed over different concentrations factors in a batch operation for the 551 virgin membranes, the membranes after milk concentration followed by a water rinse and the 552 membranes after milk or whey concentration followed by a three step CIP procedure. Water was 553 used as the feed and an $\mathrm{NaCl}$ solution of $48 \pm 1 \mathrm{~g} / \mathrm{L}$ was as the draw solution. (Volume of $\mathrm{FS}=140 \mathrm{~L}$, 554 volume of $\mathrm{DS}=160 \mathrm{~L}$ ).

555 Figure 10: Water flux observed for different total solids concentrations for skim milk, Whey Sample A 556 and Whey Sample B tested by the FO pilot plant. All experiments were conducted at room

557 temperature in batch mode, with an initial draw solution ( $\mathrm{NaCl}$ ) of $48 \pm 1 \mathrm{~g} / \mathrm{L}$ and a TMP of $1.0 \pm 0.1$ 558 bar. Insert: Water flux is plotted against concentration factor for all the dairy samples. (Volume of FS $559=140 \mathrm{~L}$, volume of $\mathrm{DS}=160 \mathrm{~L}$ )

560 Figure 11: Specific electrical energy consumption for the concentration of skim milk (SM2) and Whey 561 Sample B over a range of total solids concentrations. The grey area represents the typical range of 562 energy consumption reported for milk concentration using reverse osmosis [30, 31]. 